\title{
Penerapan Model Pembelajaran Tipe Jigsaw untuk Meningkatkan Hasil Belajar Mata Pelajaran Sejarah pada Kompetensi Dasar Mendiskripsikan Tradisi Sejarah
}

\author{
Titik Rohmawati \\ Sekolah Menengah Atas (SMA) Negeri 1 Mlonggo Jepara \\ Email Korespodensi: titikrochmawati@gmail.com
}

\begin{abstract}
ABSTRAK: Sejarah merupakan salah satu mata pelajaran yang memerlukan pemikiran kritis dalam memandang segala sesuatu peristiwa yang terjadi di masa lampau. Penelitian ini bertujuan untuk mengetahui aktivitas dan peningkatan hasil belajar siswa, serta terjadinya perubahan sikap dan tingkah laku siswa terhadap model pembelajaran tipe jigsaw. Penelitian ini menggunakan pendekatan kuantitatif untuk memperoleh data dan analisisnya melalui kajian-kajian reflektif, partisipatif, dan kolaboratif. Pada kegiatan berikutnya dilakukan pengembangan program pembelajaran berdasarkan pada data-data baik yang diperoleh dari siswa, guru dan setting kegiatan sosial antar siswa maupun siswi dengan guru baik di dalam kelas maupun diluar kelas. Setiap kegiatan pembelajaran pada penelitian ini direncanakan terlebih dahulu dan dilaksanakan melalui tiga macam siklus. Untuk meningkatkan kegiatan pembelajaran digunakan pendekatan pembelajaran kooperatif learning tipe jigsaw. Setelah dilaksanakan penelitian tindakan kelas maka dapat diperoleh data-data hasil evaluasi kegiatan belajar siswa melalui ulangan ke 1 yaitu 64 (belum menggunakan pembelajaran kooperatif learning tipe jigsaw). Setelah menggunakan jigsaw maka hasil evaluasi kegiatan belajar siswa melalui ulangan meningkat menjadi 71 pada siklus I, 73 pada.siklus II dan 76 pada siklus III. Adapun prosentase tingkat ketuntasan belajar siswa secara klasikal sebelum menggunakan jigsaw adalah $56 \%$, setelah menggunakan jigsaw secara bertahap mengalami peningkatan dari $72 \%$ pada siklus I, $86 \%$ pada siklus II dan $100 \%$ pada siklus III.
\end{abstract}

Kata kunci: Aksara, Jigsaw, Tradisi Sejarah, Praaksara.

ABSTRACT: History is one of the subjects that requires critical thinking in looking at all the events that happened in the past. This study aims to determine the activities and increase student learning outcomes, as well as changes in student attitudes and behavior towards the jigsaw type learning model. This research uses a quantitative approach to obtain data and analysis through reflective, participatory and collaborative studies. In the next activity, the development of learning programs is carried out based on good data obtained from students, teachers and the setting of social activities between students and students with teachers both inside and outside the classroom. Each learning activity in this study is planned in advance and implemented through three kinds of cycles. To improve learning activities used a jigsaw cooperative learning approach. After carrying out classroom action research, data can be obtained from the results of the evaluation of student learning activities through the first test, which is 64 (not using the jigsaw cooperative learning type). After using the jigsaw, the results of the evaluation of student learning activities through tests increased to 71 in cycle I, 73 in cycle II and 76 in cycle III. The percentage level of classical student learning completeness before using jigsaw was 56\%, after using jigsaw gradually increased from $72 \%$ in cycle I, $86 \%$ in cycle II and 100\% in cycle III.

Key words: Jigsaw, Historical Tradition, Praaksara, Script 


\section{PENDAHULUAN}

Proses pembelajaran dan hasil belajar siswa merupakan indikator dari keberhasilan pendidikan. Kenyataan yang terjadi di dalam kelas merupakan suatu fenomena yang menunjukan bahwa pendidikan telah berhasil atau belum. Di mana hasil belajar yang diharapkan baik oleh guru maupun orang tua adalah terjadinya peningkatan seluruh potensi yang dimiliki siswa, seperti kognitif, afektif dan psikomotorik.

Menurut (Syamsuriyanti \& Sukirno, 2017; Ling (1981) belajar adalah suatu proses adaptasi atau penyesuaian tingkah laku yang berlangsung secara progresif. Proses adaptasi akan mendatangkan hasil yang optimal apabila diberi penguatan. Sedangkan menurut July \& Bennett (2009) belajar adalah suatu perubahan yang terjadi dalam diri organisme disebabkan oleh pengalaman yang dapat mempengaruhi tingkah laku organisme. Pengalaman hidup sehari-hari dalam bentuk apapun sangat memungkinkan untuk diartikan sebagai belajar.

Oleh karena itu, maka siswalah yang seharusnya turut berpartisipasi aktif dalam kegiatan belajar, sedangkan guru hanya berperan sebagai mediator, moderator, fasilitator dan organisator (Piyush Shivam, 2007; Sugiyanto, 2009)

Hasil belajar yang diharapkan kadang kala tidak dapat mencapai tujuan yang sudah ditetapkan baik didalam standar kompetensi lulusan maupun kriteria ketuntasan minimal, tetapi hanya sebagian kecil saja yang dapat mencapainya. Hal ini dapat terjadi karena sebagian besar siswa masih beranggapan bahwa hasil belajara lebih penting, sedangkan proses belajar diabaikan. Oleh karena itu apabila hasil belajar yang diperoleh menurun maka akan berpengaruh pada turunnya tingkat aktivitas belajar siswa (Musadad, 2011; Syah, 1995).

Metode pembelajaran konvensional biasanya akan berlangsung monoton tanpa ada teknik kreatif yang mengajak siswa untuk berperan aktif dalam mengikuti proses pembelajaran dan memotivasi siswa untuk lebih serius terhadap mata palajaran. Sehingga terjadi proses pembelajaran yang inovatif antara guru dengan siswa dan antara siswa dengan siswa karena metode yang diberikan dalam proses pembelajaran bisa merangsang siswa untuk termotivasi mengikuti proses belajar mengajar (Rindu \& Ariyanti, 2017; Hidayatullah, 2010).

Pembelajaran yang menarik salah satunya diadapatkan dari inovasi pendidikan yang diterapkan oleh guru dalam proses belajar mengajar. Inovasi pendidikan tidak hanya pada inovasi sarana dan prasarana pendidikan serta kurikulum saja melainkan juga proses pendidikan itu sendiri. Inovasi dalam proses pembelajaran sangat diperlukan guna meningkatkan prestasi kearah yang maksimal. Inovasi ini dapat dilakukan dengan beberapa pendekatan pembelajaran, strategi pembelajaran dan metode pembelajaran. Kewajiban sebagai pendidik atau guru tidak hanya transfer pengetahuan tapi juga dapat mengubah prilaku, memberikan dorongan yang positif sehingga siswa termotivasi, memberi suasana belajar yang menyenangkan, agar mereka bisa berkembang semaksimal mungkin. Guru tidak hanya mengolah otak siswanya tapi juga mengolah jiwa anak didiknya supaya terjadi keseimbangan antara prestasi akademik dengan kondisi kejiwaan siswa (Sulasmi, 2014).

Model pembelajaran konvensional yang sering dilakukan guru untuk sekarang dapat dikatakan sebagai model yang tidak bisa mengikuti zaman yang sudah semakin modern seiring dengan kemajuan dalam bidang pendidikan. Sudah seharusnya seorang guru mempunyai metode atau model-model pembelajaran yang lebih inovatif untuk mengantisipasi kelemahan model konvensional yang selama ini dipakai guru. 
Model saling ketergantungan (cooperative learning) dalam mencapai tujuan pembelajaran berupa: 1) Saling ketergantungan dalam melaksanakan tugas, terhadap bahan atau sumber belajar, 2) Saling ketergantungan dalam didalam memainkan perannya masing-masing, dan 3) Saling ketergantungan memperoleh hasil atau hadiah yang diinginkan (Orprayoon, 2014). Model pembelajaran kooperatif adalah suatu pendekatan pembelajaran yang berfokus pada penggunaan kelompok kecil agar dapat bekerjasama dalam memaksimalkan kondisi belajar untuk mencapai suatu tujuan. Di mana model pembelajaran ini bertujuan untuk mengembangkan aspek ketrampilan sosial sekaligus ketrampilan kognitif dan aspek sikap siswa. Dalam model pembelajaran kooperatif tersebut guru berusaha untuk menciptakan suasana belajar yang mendorong siswa saling membutuhkan dan saling ketergantungan positif satu sama lain.

Julinar (2014) \& Slavin (1985) menjelaskan bahwa cooperative learning suatu model pembelajaran dimana siswa belajar dan bekerja dalam kelompokkelompok kecil secara kolaboratoratif yang anggotanya terdiri dari 4 sampai 6 orang dengan struktur kelompok yang bersifat heterogen dan keberhasilan belajar dari kelompok tergantung pada kemampuan dan aktivitas anggota kelompok, baik secara individual maupun secara kelompok.

Kooperatif Tipe Jigsaw merupakan model pembelajaran yang memberikan kesempatan yang luas kepada siswa untuk melakukan kegiatan belajarnya secara bekerjasama dengan kelompok-kelompok yang dibuat oleh guru. Sehingga diharapkan dengan model pembelajaran Kooperatif Tipe Jigsaw, siswa diharapkan dapat lebih bisa menemukan masalah, mengorganisasikan, memecahkan masalah dan bekerjasama dalam menanggapi masalah. Sebagai model pembelajaran yang berpusat pada siswa maka dengan menerapakan metode ini, siswa dalam proses belajar di kelas akan lebih aktif, lebih bisa mempertimbangkan pendapat dan lebih memotivasi siswa dalam mengikuti proses pembelajaran yang terjadi di kelas (Andrias, 2011).

Kooperatif mengandung pengertian bekerja bersama dalam mencapai tujuan bersama (Suprijono, 2012). Kooperatif dalam hal ini adalah kerjasama antar siswa dengan siswa dan antar siswa dengan kelompoknya dan dituntut juga tanggung jawab baik terhadap diri sendiri maupun terhadap kelompok (Muslaini, 2017). Model pembelajaran kooperatif tipe Jigsaw merupakan model pembelajaran kooperatif dimana siswa belajar dalam kelompok kecil yang terdiri dari 4-6 orang dengan memperhatikan keheterogenan, bekerjasama positif dan setiap anggota bertanggung jawab untuk mempelajari masalah tertentu dari materi yang diberikan dan menyampaikan materi tersebut kepada anggota kelompok yang lain (Mehta \& Kulshrestha, 2014). Keunggulan kooperatif tipe jigsaw meningkatkan rasa tanggung jawab siswa terhadap pembelajarannya sendiri dan juga pembelajaran orang lain. Siswa tidak hanya mempelajari materi yang diberikan, tetapi mereka juga harus siap memberikan dan mengajarkan materi tersebut pada anggota kelompoknya yang lain selain itu dapat meningkatkan kerjasama secara kooperatif untuk mempelajari materi yang ditugaskan (Mengduo \& Xiaoling, 2010; Suryanti, 2009).

Maka dengan menggunakan metode pembelajaran yang tepat, diharapkan dapat memberikan peningkatan motivasi belajar siswa dalam mengikuti proses pembelajaran. Sehingga terjadi kerjasama yang baik antara guru dengan siswa dan antara siswa dengan siswa yang berlandaskan tanggung jawab penuh atas apa yang menjadi tujuan dalam proses pembelajaran. Dengan begitu akan tercipta proses pembelajaran yang 
bermakna dan tercapainya tujuan dari pembelajaran tersebut yang kemudian terlihat dalam bentuk hasil evaluasi pembelajaran yaitu berupa nilai yang didapatkan siswa dan prestasi hasil belajar yang diraih siswa (Trianto, 2011 \& Brown, 2013)

Sejarah merupakan salah satu mata pelajaran yang memerlukan pemikiran kritis dalam memandang segala sesuatu peristiwa yang terjadi di masa lampau. Dalam mata pelajaran sejarah, siswa diberikan suatu gambaran berupa fakta-fakta yang terjadi yang terjadi pada masa lalu. Seharusnya mata pelajaran sejarah memberikan rangsangan pada siswa untuk berpikir kritis mengenai peristiwa yang terjadi pada masa lampau dan berpikir skeptis terhadap apa yang dikatakan oleh guru ataupun sumber buku yang menjadi pegangan. Sehingga dengan begitu siswa dapat berperan aktif dalam mengikuti proses pembelajaran dan pembelajaran berlangsung dengan sangat menarik (Irani et al., 2018; Mastati, 2017).

Dilaksanakannya penelitian tindakan kelas ini berangkat dari latar belakang perlunya pembaruan dalam kegiatan belajar mengajar baik yang dilakukan oleh guru maupun oleh siswa khususnya pada mata pelajaran sejarah. Rendahnya aktivitas siswa dalam proses pembelajaran dapat berpengaruh pada hasil belajar siswa yang tidak sesuai dengan kriteria ketuntasan minimal yang ditetapkan oleh sekolah. Hal ini juga tidak hanya terjadi pada diri siswa, tetapi dipengaruhi oleh peran guru sebagai fasilitator, motivator serta masih digunakannya pendekatan pembelajaran tradisional, materi pembelajaran tidak kontekstual (Tandirerung, n.d.).

Kegiatan pembelajaran yang masih menggunakan pendekatan secara tradisional dapat menimbulkan kejenuhan, kebosanan serta dapat menurunkan semangat, minat dan motivasi siswa dalam belajar. Dengan demikian penelitian tindakan kelas sangat berperanan penting dalam meningkatkan mutu kegiatan pembelajaran agar guru selalu mengadakan inovasi atau pembeharuan baik terhadap perencanaan, pelaksanaan, evaluasi, maupun menganalisis kegiatan pembelajaran (Riyadi, 2016; Kusnandar, 2012).

Tujuan penelitian adalah untuk mengetahui aktivitas, dan peningkatan hasil belajar siswa, serta terjadinya perubahan sikap dan tingkah laku siswa terhadap model pembelajaran tipe jigsaw.

\section{METODE PENELITIAN}

Metodologi Penelitian yang dilakukan dalam penelitian ini menggunakan Model Penelitian Tindakan Kelas dimana bertujuan untuk meningkatkan mutu proses dan hasil pembelajaran di kelas dengan melaksanakan tahap-tahap PTK peneliti menemukan solusi dari masalah yang timbul di dalam kelas. Seperti yang dikatakan oleh Kemmis dan Mc Taggart, yang mengatakan bahwa PTK adalah suatu bentuk refleksi diri kolektif yang dilakukan oleh peserta-pesertanya dalam situasi sosial untuk meningkatkan penalaran dan keadilan praktik-praktik itu dan terhadap situasi tempat dilakukan praktik-praktik tersebut (Kunandar, 2010).

Pendapat yang dikemukakan oleh Kemmis dan MC Taggart memang masih sangat umum, kemudian pendapat tersebut lebih di kerucutkan lagi oleh Hardjodipuro bahwa yang dimaksud dengan istilah PTK adalah: suatu bentuk refleksi diri yang dilakukan oleh para partisipan (guru, siswa atau kepala sekolah) dalam situasi-situasi sosial (termasuk pendidikan) untuk memperbaiki rasionalitas dan kebenaran (a) praktik-praktik sosial atau pendidikan yang dilakukan dilakukan sendiri, (b) pengertian mengenai praktik-praktik ini, dan (c) situasisituasi ( dan lembaga-lembaga ) tempat praktik-praktik tersebut dilaksanakan (Aqib, 2009). 
Berdasarkan pendapat-pendapat di atas dapat disimpulkan bahwa PTK di lakukan dalam rangka memecahkan masalah dikelas oleh guru melalui intropeksi, bercermin, merefleksi atau mengevaluasi diri sendiri sehingga kemampuannya sebagai seorang guru/pengajar sudah memadai dan diharapkan dapat meningkatkan kualitas anak didiknya, baik dalam aspek penalaran, keterampilan, pengetahuan hubungan sosial maupun aspek-aspek lain yang bermanfaat bagi anak didik dan untuk meningkatkan kualitas pendidikan pada umumnya.

\section{Desain Penelitian}

Model Penelitian Tindakan Kelas ini menggunakan desain model penelitian Kemmis dimana dalam desain ini Kemmis menggunakan empat komponen penelitian tindakan yaitu perencanaan, tindakan, observasi dan refleksi dalam suatu sistem spiral yang saling terkait antara yang satu dengan yang lainnya. Kemmis dan Mc Taggart, yang mengatakan bahwa PTK adalah suatu bentuk refleksi diri kolektif yang dilakukan oleh peserta-pesertanya dalam situasi sosial untuk meningkatkan penalaran dan keadilan praktik-praktik itu dan terhadap situasi tempat dilakukan praktik-praktik tersebut (Santyasa, 2007).

Alasan menggunakan desain tersebut dalam penelitian ini yaitu dikarenakan model penelitian Kemmis dalam penerapannya dilakukan secara berulang-ulang atau ada perencanaan ulang setelah tindakan pertama. Sehingga kita bisa menarik kesimpulan jika pada penelitian pertama tidak berhasil kita akan melakukan penelitian selanjutnya. Dengan model penelitian Kemmis kita mengetahui apakah berhasil atau tidaknya suatu perencaan.

Selain itu penelitian model Kemmis menggunakan empat komponen penelitian tindakan diantaranya: perencaan, tindakan, observasi dan refleksi dalam suatu system spiral yang saling terkait. Perencanaan merupakan tahap awal yang sangat penting untuk di lakukan, karena dengan dilakukanya perencanaan terlebih dahulu maka tindakan yang dilakukan akan tersusun secara sistematis. Kemudian dilanjutkan dengan melakukan tindakan atau proses yang diperlukan dalam penelitian tersebut dan proses selanjutnya mulai melakukan observasi, dalam hal ini penelitian menggunakan metode Kooperatif Jigsaw untuk meningkatkanhasil belajar siswa kelas $X$ di SMA Negeri 1 Mlonggo. Setelah proses observasi selesai maka akan dilakukan refleksi atau analisis terhadap data yang telah dihasilkan dan jika terjadi kesalahan akan dilakukan pengumpulan data kembali sehingga pada akhirnya menghasilkan data yang benar-benar valid dan tercapai pada tujuan yang ingin di capai yaitu meningkatkan motivasi siswa.

\section{Population dan Sampel}

Penelitian tindakan kelas ini dilaksanakan di SMA Negeri 1 Mlonggo, Kabupaten Jepara, dengan mengambil obyek penelitian pada kelas X. Di pilinnya kelas X 6 karena berkaitan dengan masalah yang sedang diteliti oleh penulis, yakni mengenai rendahnya hasil belajar pada mata pelajaran sejarah.

Penelitian tindakan kelas ini dilaksanakan selama 4 (empat) bulan, yakni antara bulan September 2019 sampai dengan bulan Desember 2019. Adapun pelaksanaan kegiatan ini dimulai dari penyusunan proposal dan instrumen pada bulan September 2019. Kemudian pada bulan Oktober dan Nopember 2019 dilakukan pengumpulan data melalui tindakan pada siklus I dan siklus II. Terhadap data-data yang telah diperoleh, kemudian dilakukan analisis dan pembahasan pada bulan Desember 2019. Setelah proses analisis dan pembahasan selesai, maka pada bulan Desember 2019 penulis menyusun laporan hasil penelitian tindakan kelas. 
Subjek yang diambil pada penelitian tindakan kelas ini adalah siswa-siswi di kelas $X \quad 6$ SMA Negeri 1 Mlonggo. Sedangkan jumlah siswa yang terdapat dalam kelas $X 6$ adalah 15 orang laki-laki dan 21 orang perempuan.

\section{Teknik Pengumpulan Data}

Untuk mendapatkan data tentang hasil belajar siswa maka digunakan teknik tes yang terdiri dari 5 (lima) butir soal tes tertulis guna mengukur hasil belajar siswa. Sedangkan untuk mengetahui tingkat aktivitas dan partisipasi siswa dalam kegiatan belajar maka digunakan teknik observasi yang berupa lembar observasi aktivitas belajar siswa.

\section{Validasi Data}

Untuk memperoleh data yang valid, maka terlebih dahulu perlu disusun instrument penelitian. Agar terpenuhi validitas teoritik, terutama validitas isi (Content Validity) disusunlah kisi-kisi soal untuk ulangan harian yang berkaitan dengan kompetensi dasar mendeskripsikan tradisi sejarah dalam masyarakat Indonesia masa praaksara dan masa aksara.

\section{Teknik Analisis Data}

Data yang diperoleh pada penelitian ini adalah berupa data kuantitatif mengenai tugas individu dan tugas kelompok. Selain itu diperlukan pula data kualitatif yang berasal dari hasil ulangan harian siswa. Untuk itu digunakan analisis deskriptif komparatif, yaitu membandingkan nilai hasil ulangan harian kondisi awal (sebelum dilakukan penelitian), hasil ulangan harian siklus 1 hasil ulangan harian pada siklus II dan hasil ulangan harian pada siklus III (Kunandar, 2010).

Dalam kegiatan Penelitian Tindakan Kelas ini akan melihat indikator kinerja baik pada guru maupun siswa. Karena fungsi guru sebagai fasilitator sangat besar pengaruhnya pada kinerja siswa. Indikator kinerja guru terdiri dari dokumentasi yaitu berupa kehadiran siswa dan observasi yaitu hasil pengamatan terhadap kegiatan belajar siswa. Adapun indicator kinerja siswa terdiri dari rata-rata hasil nilai ulangan harian dan observasi yaitu berupa keaktifan siswa dalam proses belajar mengajar mata pelajaran sejarah.

\section{Prosedur Penelitian}

Desain penelitian dalam penelitian tindakan kelas ini, mengacu pada model Kurt Lewin. Komponen pokok dalam penelitian tindakan kelas Kurt Lewin adalah perencanaan (planning), pelaksanaan (acting), pengamatan (observing), dan refleksi (reflecting) (Depdiknas, 2007). Hubungan keempat konsep pokok tersebut diuraikan beberapa kegiatan sebagai berikut:

1. Siklus I

a. Perencanaan (Planning), berupa kegiatan: (1) Peneliti atau guru melakukan analisis kurikulum untuk mengetahui kompetensi dasar yang akan disampaikan kepada siswa dengan menggunakan model pembelajaran kooperatif learning tipe jigsaw; (2) Membuat rencana pembelajaran menggunakan model pembelajaran kooperatif learning tipe jigsaw; (c) Membuat lembar kerja siswa; (d) Membuat instrumen yang akan digunakan pada siklus Penelitian Tindakan Kelas; (d) Menyusun alat evaluasi pembelajaran.

b. Tindakan (Acting), berupa kegiatan: (1) Guru membagi siswa menjadi delapan kelompok yang terdiri satu kelompok pakar dan tujuh kelompok asal ( home group ) dari dengan anggota antara 4-5 orang siswa; (b) Menyajikan materi pembelajaran; (c) Setiap kelompok diberi materi 
diskusi;(d) Guru mengarahkan siswa dalam diskusi kelompok; (e) Salah satu wakil pada setiap kelompok mempresentasikan hasil diskusi didepan kelas;,(f) Siswa diberi kesempatan untuk memberikan tanggapan terhadap presentasi yang disampaikan oleh wakil setiap kelompok; (g) Guru memberikan kuis atau pertanyaan; (h) Guru melakukan pengamatan terhadap kegiatan belajar siswa; (i) Guru bersama siswa melakukan penguatan dan membuat kesimpulan hasil belajar siswa.

a. Pengamatan (Observasi), berupa kegiatan: (a) Guru mengamati kegiatan belajar siswa; (b) Guru mengamati keaktifan siswa dalam kegiatan belajar; (c) Guru mengamati kemampuan kerjasama siswa dalam diskusi kelompok.

b. Refleksi, Penelitian Tindakan Kelas ini dapat berhasil jika sudah memenuhi beberapa syarat sebagai berikut: (1) Sebagian besar siswa atau $75 \%$ dari sejumlah siswa sudah berani dan mampu menjawab pertanyaan dari guru; (b) Sebagian besar siswa atau $70 \%$ dari sejumlah siswa sudah berani menanggapi dan mengemukakan pendapat tentang jawaban siswa yang lain; (c) Sebagian besar siswa atau $70 \%$ dari sejumlah siswa sudah berani dan mampu bertanya tentang materi pembelajaran pada guru; (d) Lebih dari $80 \%$ anggota kelompok aktif dalam mengerjakan tugas kelompoknya; (e) Kelompok dapat menyelesaikan tugas dari guru sesuai dengan waktu yang disediakan.

2. Siklus II

a. Perencanaan (Planning), yaitu peneliti membuat rencana pembelajaran berdasarkan hasil refleksi pada siklus pertama.

b. Pelaksanaan (Acting), yaitu guru melaksanakan model pembelajaran kooperatif learning tipe jigsaw berdasarkan rencana pembelajaran hasil refleksi pada siklus pertama.

c. Pengamatan ( Observasi ), yaitu Peneliti melakukan pengamatan terhadap aktivitas pembelajaran model kooperatif learning tipe jigsaw.

d. Refleksi (Reflecting), yaitu peneliti melakukan refleksi terhadap pelaksanaan siklus kedua dan menyusun rencana ( planning) untuk siklus ketiga.

3. Siklus III

a. Perencanaan (Planning): peneliti membuat rencana pembelajaran berdasarkan hasil refleksi pada siklus kedua.

b. Pelaksanaan (Acting): guru melaksanakan pembelajaran model kooperatif learning tipe jigsaw berdasarkan rencana pembelajaran hasil refleksi pada siklus kedua.

c. Pengamatan (Observasi): peneliti melakukan pengamatan terhadap aktivitas pembelajaran model kooperatif learning tipe jigsaw.

d. Refleksi (Reflecting): peneliti melakukan refleksi terhadap pelaksanaan siklus ketiga dan menyusun analisis serta membuat kesimpulan atas pelaksanaan pembelajaran model kooperatif learning tipe jigsaw untuk meningkatkan aktivitas dan hasil belajar siswa dalam embelajaran sejarah. 


\section{HASIL PENELITIAN DAN PEMBAHASAN}

\section{Deskripsi Awal}

Sebagaimana disampaikan oleh (Kunandar, 2010), PTK adalah suatu bentuk refleksi diri kolektif yang dilakukan oleh peserta-pesertanya dalam situasi sosial untuk meningkatkan penalaran dan keadilan praktik-praktik itu dan terhadap situasi tempat dilakukan praktik-praktik tersebut Berdasarkan data penelitian, ditemukan hasil ulangan harian ke 1 sebagaimana termuat dalam Tabel berikut:

Tabel 1 Data hasil ulangan harian ke 1

\begin{tabular}{|r|l|c|}
\hline No & Keterangan & $\begin{array}{l}\text { Ulangan } \\
\text { Harian } \\
\text { Ke 1 }\end{array}$ \\
\hline 1 & Rata - rata & 64 \\
\hline 2 & Nilai tertinggi & 70 \\
\hline 3 & Nilai terendah & 55 \\
\hline 4 & Jumlah siswa & 36 \\
\hline 5 & $\begin{array}{l}\text { Siswa yang belum } \\
\text { tuntas }\end{array}$ & 16 \\
\hline 6 & $\begin{array}{l}\text { Siswa yang sudah } \\
\text { tuntas }\end{array}$ & 20 \\
\hline 7 & $\begin{array}{l}\text { Prosentase } \\
\text { ketuntasan }\end{array}$ \\
\hline
\end{tabular}

Sebelum penelitian tindakan kelas dilaksanakan, tingkat penguasaan siswa terhadap materi sejarah pada kompetensi dasar "Menjelaskan pengertian dan ruang lingkup sejarah" masih sangat rendah. Berdasarkan hasil analisis ulangan harian dapat diketahui bahwa dari sejumlah 36 orang siswa pada kelas $X 6$ hanya 20 orang atau $56 \%$ yang dapat mencapai ketuntasan belajar. Sedangkan sisanya yaitu 16 orang atau $44 \%$ belum dapat menguasai materi pembelejaran dengan baik.

Rendahnya daya serap siswa terhadap materi pembelajaran kerena guru masih menggunakan model pembelajaran tradisional, dimana kegiatan belajar mengajar masih berpusat pada guru, sedangkan aktivitas belajar siswa masih diabaikan. Pada model pembelajaran tradisional seluruh informasi berasal dari guru, sedangkan siswa hanya menerima secara pasif. Siswa hanya mengerjakan semua tugas yang disampaikan oleh guru, tetapi tidak pernah memperoleh umpan balik, sehingga tidak dapat mengetahui kelebihan dan kekurangannya. Model pembelajaran yang berpusat pada guru tersebut dapat menimbulkan kejenuhan, rendahnya partisipasi dan aktifitas belajar pada siswa.

Untuk mengatasi masalah tersebut hendaknya guru melakukan perbaikan baik terhadap perencanaan dan pelaksanaan kegiatan pembelajaran yang menggunakan model pembelajaran kooperatif learning tipe jigsaw. Kemudian mengadakan pembinaan kepada siswa agar dapat memahami dan melaksanakan model pembelajaran kooperatif learning tipe jigsaw.

\section{Hasil Penelitian Siklus I}

Terlebih dahulu peneliti atau guru menyusun perencanan dengan melakukan analisis terhadap kurikulum untuk menentukan standar kompetensi dan kompetensi dasar yang akan disampaikan kepada siswa. Kemudian memahami langkah-langkah model pembelajaran kooperatif learning tipe jigsaw dan membuat rencana pembelajaran menggunakan model pembelajaran kooperatif learning tipe jigsaw. Membuat lembar kerja siswa dan menyusun alat evaluasi pembelajaran.

Pelaksanaan pembelajaran pada saat awal siklus pertama, belum sesuai dengan rencana. Hal ini disebabkan karena sebagain siswa belum terbiasa dengan kondisi belajar berkelompok. Serta masih terdapat kelompok yang belum dapat memahami dan melaksanakan langkah-langkah model 
pembelajaran kooperatif learning tipe jigsaw secara utuh dan menyeluruh. Untuk mengatasi masalah tersebut diatas maka perlu dilakukan upaya dengan memberi pengertian kepada siswa mengenai kondisi kelompok, kerjasama kelompok, keikutsertaan siswa dalam kelompok. Selanjutnya guru membantu dan membimbing kelompok yang belum memahami langkah-langkah model pembelajaran kooperatif learning tipe jigsaw.

Pada saat saat akhir siklus pertama guru memperoleh kesimpulan bahwa siswa mulai terbiasa dengan kondisi belajar berkelompok, dapat memahami dan melaksanakan langkah-langkah model pembelajaran kooperatif learning tipe jigsaw.

Hasil evaluasi siklus I yang berkaitan dengan penguasaan siswa terhadap materi pembelajaran sudah menacapai katergori baik dengan perolehan skor nilai rata-rata yaitu 71. Dimana setelah hasil ulangan harian ke 2 dianalisis hanya 26 orang atau 72 $\%$ yang dapat mencapai ketuntasan, sedangkan sisanya yaitu 10 orang atau $28 \%$ belum tuntas. Meskipun tingkat ketuntasan belajar pada siklus I belum dapat mencapai $75 \%$ sudah mulai ada peningkatan jika dibandingkan dengan hasil ulangan harian ke 1 yang belum menggunakan model pembelajaran kooperatif tipe jigsaw.

Untuk memperbaiki pelaksanaan pembelajaran pada siklus I maka perlu diadakan refleksi dan perencanaan ulang. Langkah-langkah perbaikan hendaknya memperhatikan kondisi siswa yang belum terbiasa dengan model pembelajaran kooperatif learning tipe jigsaw, sehingga masih merasa kurang senang dan antusias dalam belajar. Sedangkan terhadap kelompok yang belum menyelesaikan tugas dengan waktu tepat waktu dan belum dapat mempresentasikan hasil tugasnya perlu mendapat perhatian dan bimbingan yang intensif.

Untuk meperbaiki kelemahan dan mempertahankan keberhasilan yang telah dicapai pada siklus pertama, maka pada pelaksanaan siklus kedua guru perlu memberikan motivasi dan membimbing kelompok agar lebih aktif dan dapat menguasai langkah-langkah model pembelajaran kooperatif learning tipe jigsaw. Sedangkan bagi kelompok yang sudah yang sudah menguasai model pembelajaran kooperatif learning tipe jigsaw hendaknya guru perlu memberikan pengakuan atau penghargaan (reward).

\section{Deskripsi Hasil Penelitian Siklus II}

Seperti pada siklus pertama siklus kedua terdiri dari empat tahap yakni perencanaan, pelaksanaan, observasi dan refleksi serta replaning, sebagai berikut :

a. Perancanaan pada siklus kedua berdasarkan planing siklus pertama, dimana guru memberikan motivasi kepada kelompok agar lebih aktif lagi dalam kegiatan pembelajaran. Kemudian membimbing kelompok yang masih mengalami kesulitan pada kegiatan diskusi serta memberikan pengakuan atau penghargaan pada kelompok yang sudah mampu melaksanakan kegiatan diskusi.

b. Pada pelaksanaan pembelajaaran siklus II suasana pembelajaran sudah mengarah pada model pembelajaran kooperatife learning tipe jigsaw. Siswa sudah mampu mengerjakan lembar kerja akademik yang diberikan oleh guru dengan baik dan tepat waktu. Selain itu sudah terdapat aktivitas siswa untuk saling membantu dalam menguasai materi pelajaran melalui kegiatan diskusi antar sesama 
kelompok. Sebagian besar siswa merasa termotivasi untuk bertanya dan menanggapi suatu presentasi dari kelompok lain sehingga pada gilirannya sudah tercipta suasana pembelajaran yang efektif dan menyenangkan.

c. Hasil evaluasi penguasaan siswa terhadap materi pembelajaran pada siklus kedua melalui ulangan harian ke 3 sudah termasuk kategori baik yakni dari skor ideal 100 nilai ratarata skor perolehan adalah 73 . Selain itu prosentase ketuntasan belajar sudah mengalami kenaikan dari $72 \%$ pada siklus I menjadi $86 \%$ pada siklus II.

d. Refleksi dan Perencanaan Ulang terhadap pelaksanaan pembelajaran pada siklus II mengalami kemajuan perlu ditindak lanjuti agar kegiatan pembelajaran pada siklus III mencapai kemajuan yang lebih optimal. Hal ini didasarkan pada kegiatan pembelajaran siklus II yang sudah mengalami kemajuan dimana aktivitas siswa dalam kegiatan belajar sudah mengarah ke pembelajaran kooperatif dan siswa sudah dapat menjalin kerjasama kelompok dengan baik. Sehingga pada kegiatan belajar siklus II ini siswa dapat memahami dan menyelesaikan tugas yang diberikan oleh guru dengan baik dan tepat waktu. Kemudian pada akhir kegiatan diskusi siswa sudah dapat mempresentasikan hasil kerjanya. Terjadinya peningkatan aktivitas belajar siswa tidak lepas dari peran guru yang sudah memberikan bimbingan secara intensif terhadap siswa yang masih mengalami kesulitan dalam diskusi kelompok.
Sehingga pada siklus II guru sudah dapat mempertahankan suasana pembelejaran model kooperatif tipe jigsaw serta dapat meningkatkan hasil belajar siswa melalui ulangan harian ke 3 dengan perolehan skor nilai rata-rata yaitu 73 sedangakan tingkat ketuntatasan belajar siswa pada siklus ketiga naik menjadi 86 $\%$.

\section{Deskripsi Hasil Penelitian Siklus III}

Siklus ketiga terdiri dari empat tahap yakni perencanaan, pelaksanaan, observasi dan refleksi serta replaning, sebagai berikut :

a. Perancanaan (Planing) pada siklus ketiga ini berdasarkan replaning siklus kedua dimana guru memberikan motivasi dan membimbing siswa agar dapat meningkatkan aktivitas belajar melalui diskusi kelompok. Kemudian memberikan pengakuan kepada kelompok yang dapat menyelesaikan tugas dengan baik dan tepat waktu.

b. Pada pelaksanaan siklus III suasana pembelajaran sudah lebih maju lagi yang mengarah pada pembelajaran kooperatif learning tipe jigsaw. Dimana setiap kelompok sudah mampu mengerjakan lembar kerja akademik yang diberikan oleh guru dengan lebih baik lagi. Sudah menunjukkan adanya usaha saling membantu dan kerjasama baik antar siswa maupun kelompok untuk menguasai materi pembelajaran melalui kegiatan diskusi dan tanya jawab. Siswapun sudah termotivasi untuk mempresentasikan hasil diskusi kelompok dan memberikan tanggapan terhadap hasil diskusi kelompok lain. Dengan demikian pelaksanaan pembelajaran pada siklus III ini sudah tercipta suasana 
pembelajaran yang efektif dan menyenangkan.

c. Hasil evaluasi pada siklus ketiga penguasaan siswa terhadap materi pembelajaran melalui ulangan harian ke 4 dengan perolehan nilai rata-rata 76 dari skor ideal 100. Hal ini menunjukkan bahwa tingkat penguasaan materi pelajaran sejarah oleh siswa sudah termasuk kategori sangat baik dengan prosentase tingkat ketuntasan belajar mencapai $100 \%$ dari 36 orang siswa. Sedangkan pencapaian nilai tertinggi adalah 95 dan nilai terendahnya adalah 86, dengan demikian sudah dapat mencapai kriteria ketumtasan minimal (KKM) yang sudah ditetapkan yaitu 86. Sebagai bahan perbandingan pencapaian hasil belajar siswa maka dibawah ini disajikan Tabel hasil belajar siswa.

Tabel 2

perbandingan pencapaian hasil belajar siswa

\begin{tabular}{|l|l|l|l|l|l|}
\hline N & Keterangan & $\begin{array}{l}\text { Belum } \\
\text { Menggunakan } \\
\text { Jigsaw }\end{array}$ & \multicolumn{3}{|l|}{$\begin{array}{l}\text { Sudah } \\
\text { Menggunakan } \\
\text { Jigsaw }\end{array}$} \\
\cline { 2 - 6 } & UH Ke 1 & \multicolumn{2}{|l|}{$\begin{array}{l}\text { UH UH } \\
\text { Ke }\end{array}$} & Ue 3 Ke 4 \\
\hline 1 & Rata - rata & 64 & 71 & 73 & 76 \\
\hline 2 & Nilai tertinggi & 70 & 91 & 92 & 95 \\
\hline 3 & Nilai terendał & 55 & 59 & 59 & 68 \\
\hline 4 & Jumlah siswa & 36 & 36 & 36 & 36 \\
\hline 5 & $\begin{array}{l}\text { Siswa yang } \\
\text { belum tuntas }\end{array}$ & 16 & 10 & 5 & 0 \\
\hline 6 & $\begin{array}{l}\text { Siswa yang } \\
\text { sudah tuntas }\end{array}$ & 20 & 26 & 31 & 36 \\
\hline 7 & $\begin{array}{l}\text { Prosentase } \\
\text { ketuntasan }\end{array}$ & 56 & 72 & 86 & 100 \\
\hline
\end{tabular}

d. Refleksi terhadap keberhasilan yang diperoleh pada siklus ketiga karena aktivitas siswa dalam kegiatan sudah mengarah ke pembelajaran kooperatif learning tipe jigsaw dengan lebih baik lagi. Siswa sudah mampu membangun kerjasama dalam kelompok dan turut berpartisipasi aktif dalam kegiatan belajar, sehingga dapat memahami tugas yang diberikan oleh guru dan mengerjakannya dengan lebih baik serta tepat waktu. Terjadinya peningkatan aktivitas belajar ini karena siswa dalam diri sudah muncul motivasi belajar untuk memperoleh hasil yang lebih baik. Peningkatan aktivitas dan hasil belajar siswa ini karena didorong oleh keinginan guru untuk mempertahankan suasana pembelajaran yang aktif dan menyenangkan sehingga pada gilirannya siswa dapat memahami dan melaksanakan model pembelajaran kooperatif learning tipe jigsaw.

\section{SIMPULAN}

Berdasarkan hasil penelitian tindakan kelas maka dapat diambil beberapa kesimpulan. Penerapan model pembelajaran kooperatif learning tipe jigsaw dapat meningkatkan aktivitas belajar mengajar yang dapat berpengaruh terhadap hasil belajar siswa maupun jkinerja guru dalam melaksanakan kegiatan pembelajaran yang efektif dan efisien.

Hasil penguasaan siswa terhadap materi pelajaran menunjukkan adanya peningkatan dengan nilai perolehan ratarata 64 pada ulangan harian ke 1 yang belum menggunakan model pembelajaran kooperatif learning tipe jigsaw. Setelah menggunakan model pembelajaran kooperatif learning tipe jigsaw nilai ulangan harian siswa mengalami peningkatan secara bertahap yaitu pada siklus I mencapai nilai rata-rata 71 . Dengan diadakannya refleksi dan perencanaan ulang maka terjadi peningkatan yang labih baik lagi, dimana pada siklus II mencapai nilai rata-rata 73 
sedangkan pada siklus II mencapai nilai ratarata 76 .

Selanjutnya, prosentase tingkat ketuntasan belajar siswa mengalami kemajuan yang signifikan mulai dari $56 \%$ pada ulangan harian ke 1 yang belum menggunakan model pembelejaran kooperatif learning tipe jigsaw menjadi $72 \%$ pada siklus I. Sedangkan pada siklus II prosentase ketuntasan naik menjadi $86 \%$ sudah termasuk kategori baik diatas $75 \%$ dan pada akhir siklus III prosentase ketuntasan sudah termasuk kategori lebih baik yaitu menjadi $100 \%$.

Melalui pembelajaran kooperatif learning tipe jigsaw siswa dapat membangun kerjasama kelompok dalam rangka untuk memperoleh pengetahuan, langkah-langkah penyelesaian masalah dengan cara saling memberikan bantuan baik secara individual maupun kelompok. Melalui pembelajaran kooperatif learning tipe jigsaw, maka pembelajaran sejarah menjadi lebih berarti dan menyenangkan.

Dengan demikian bahwa pembelajaran kooperatif learning tipe jigsaw dapat meningkatkan aktivitas dan hasil belajar pada siswa baik secara individu maupun kelompok pada mata pelajaran sejarah. Berdasarkan kesimpulan diatas, penelitian ini merekomendasi hal-hal sebagai berikut:

1. Dalam setiap kegiatan pembelajaran sebaiknya guru menggunakan pembelajaran kooperatif learning tipe jigsaw sebagai suatu alternatif untuk meningkatkan aktivitas dan hasil belajar siswa khususnya pada mata pelajaran sejarah.

2. Karena kegiatan penelitian tindakan kelas sangat bermanfaat bagi guru dan siswa, maka diharapkan agar kegiatan ini perlu dilanjutkan agar kegiatan belajar mengajar menjadi lebih efektif dan efisien.

\section{DAFTAR PUSTAKA}

Aqib, Z. d. (2009). Penelitian Tindakan Kelas, untuk Guru. Bandung : CV. Irama Widya.

Hidayatullah, F. M. (2010). Pengembangan Profesionalisme Guru. Surakarta: UNS Press.

Isjoni. (2010). CooperativeLearning Bandung: Alfabeta.

Andrias. (2011). Pengembangan Model Pembelajaran Sejarah: Suatu Alternatif Mengatasi Kejenuhan Mahasiswa dalam Proses Belajaran Mengajar. Selami Ips, 1(Desember), 116-136.

Brown, D. (2013). Cooperative learning. Delving into Diversity: An International Exploration of Issues of Diversity in Education, 21-33. https://doi.org/10.4324/9781315617 145-11

Irani, P. R., Habibah, W. N., Gladys, I., Eldiansyah, I., Soepeno, B., \& Puji, R. P. N. (2018). Problematik Kompetensi Guru Mata Pelajaran Sejarah Indonesia di SMKN 1 Jember. Jurnal Pendidikan Sejarah Indonesia, 1(2), 202-213.

July, O., \& Bennett, D. (2009). What is cooperative learning? ASHE-ERIC Higher Education Report, 20(4), 1-13. https://doi.org/10.1002/aehe.36402 00405

Ling, C. G. (1981). Principles of language learning and teaching. In System (Vol. 9, Issue 1, pp. 67-68). https://doi.org/10.1016/0346251x(81)90016-6

Mehta, S., \& Kulshrestha, A. K. (2014). Implementation of Cooperative Learning in Science: A Developmental-cum-Experimental 
Study. Education Research International, 2014, 1-7. https://doi.org/10.1155/2014/43154 2

Mengduo, Q., \& Xiaoling, J. (2010). Jigsaw Strategy as a cooperative learning technique: focusing on the language learners. Chinese Journal of Applied Linguistics (Foreign Language Teaching \& Research Press), 33(4), 113-125.

Musadad, A. A. (2011). Peningkatan Kreativitas dan Hasil Belajar Sejarah Indonesia Kuno Melalui Optimalisasi Model Pemecahan Masalah Kreatif Dalam Proses Belajar Mengajar (PBM) di Prodik Sejarah FKIP - UNS. Jurnal Pendidikan Dan Kebudayaan, 17(1), 1. https://doi.org/10.24832/jpnk.v17i1. 3

Muslaini. (2017). Strategies for Teaching and Reading Cpmprehension. English Educational Jurnal, 8(1), 66-77.

Orprayoon, S. (2014). Effects of Cooperative Learning on Learning Achievement and Group Working Behavior of Junior Students in Modern French Literature Course The study was aimed to test the effects of Cooperative Learning method on learning achievement of the junior French ma. The Journal of Effective Teaching, 14(141), 80-98. https://files.eric.ed.gov/fulltext/EJ10 60448.pdf

Piyush Shivam. (2007). Proactive Experiment-Driven Learning for System Management. Response.

Rindu, I., \& Ariyanti, A. (2017). Teacher's Role in Managing the Class during Teaching and Learning Process. Script Journal: Journal of Linguistic and English Teaching, 2(1), 83. https://doi.org/10.24903/sj.v2i1.77

Riyadi, S. (2016). Peningkatan
Kemampuan Guru Mata Pelajaran Sejarah dalam Merencanakan dan Melaksanakan Pembelajaran Melalui Teknik Supervisi Kunjungan Kelas. Jurnal Manajemen Dan Supervisi Pendidikan, 1(1), 24-29. https://doi.org/10.17977/um025v1i1 2016 p024

Slavin, R. E. et al. (1985). Learning to Cooperate, Cooperating to Learn. Plenum Press. https://doi.org/10.1007/978-1-48993650-9

Syamsuriyanti, \& Sukirno. (2017). Faktor Determinan Professionalisme Guru. Jurnal Kependidikan, 2(1), 56-67. https://ejournal.poltektegal.ac.id/ind ex.php/siklus/article/view/298\%0Aht tp://repositorio.unan.edu.ni/2986/1/ 5624.pdf\%0Ahttp://dx.doi.org/10.10 16/j.jana.2015.10.005\%0Ahttp://ww w.biomedcentral.com/1471-

2458/12/58\%0Ahttp://ovidsp.ovid.co m/ovidweb.cgi?T=JS\&P

Tandirerung, N. (n.d.). Pendekatan Pembelajaran Konstruktivistik Pada Siswa Kelas Xi Ips SMA Muhammadiyah 1 Palu. 1.

Sugiyanto. (2009). Model-Model Pembelajaran Inovatif. Surakarta: UNS Press.

Sulasmi. (2014). Penerapan ModelPembelajaran Kooperatif Tipe Jigsaw untuk Meningkatkan Hasil Belajar Siswa pada Mata Pelajaranllmu Pengetahuan Sosial Kelas IV di SD Mardisiswa Tambaksari Surabaya. JPGSD, 2(3).

Suprijono, A. (2012). Kooperative Learning. Yogyakarta: Pustaka Pelajar.

Suryanti, d. (2009). Model-model pembelajaran Inovatif. Surabaya: Universitas Negeri Surabaya.

Suwandi, S. (2003). Undang-Undang Nomor 20 Tahun 2003 Tentang Sistem 
Pendidikan Nasional. Jakarta: Sinar Grafika.

Syah, M. (1995). Psikologi Pendidikan Suatu Pendekatan Baru. Bandung: Remaja Rosdakarya.

Trianto. (2011). Model Pembelajaran Inovatif Progresif. Jakarta: Prestasi Pustaka. 